We also carried out experiments in vitro. Blood was shaken with labelled potassium chloride at $37^{\circ}$ in an $\mathrm{O}_{2}-\mathrm{CO}_{2}$ atmosphere for a few hours ; corpuscles and plasma were then separated. The corpuscles of rabbit blood were found to contain 35 per cent of the activity of the same volume of plasma. Taking into account, as above, the much larger potassium content of the corpuscles, we obtain 2 per cent as the extent of equipartition of the individual potassium ions between plasma and corpuscles.

We found the membrane of muscle cells to be somewhat permeable to potassium ions, as shown in the table. The ${ }^{42} \mathrm{~K}$ content of $1 \mathrm{gm}$. muscle tissue was found to be 150 per cent of that of $1 \mathrm{gm}$. plasma. If we assume, as is generally given, the extracellular volume to be 16 per cent of the muscle volume, the ${ }^{42} \mathrm{~K}$ content of the muscle cells after the lapse of twenty-four hours amounts to $1^{\cdot} 6$ as much as the ${ }^{42} \mathrm{~K}$ content of the equal weight of plasma. Taking into account that the muscle cells contain about twenty times as much potassium as plasma of the same weight, we can conclude that in the course of twentyfour hours 8 per cent of the $K+$ of the muscle cells exchanged with those present in the plasma.

In an experiment in which labelled potassium chloride was injected into the lymph sac of a frog kept at $22^{\circ}$, no ${ }^{42} \mathrm{~K}$ of any significance was found in the corpuscles after the lapse of sixteen hours, while $1 \mathrm{gm}$. of muscle tissue was found to be $2 \cdot 4$ times as active as $1 \mathrm{gm}$. plasma.

Institute of Theoretical Physics,

$$
\begin{aligned}
& \text { L. Hahn. } \\
& \text { G. Hevesy. } \\
& \text { O. RebBe. }
\end{aligned}
$$

University, Copenhagen. May 9 .

\section{Colour Reactions of Lignin and Tannins}

SEveral recent observations have led us to the view that the Mitchell colour reaction of gallotannins ${ }^{1}$ and the chlorine-sodium sulphite reaction of hardwood lignin, which latter has been studied in this Laboratory ${ }^{2,3}$, are essentially similar. The observation that ferric salts are among the oxidizing agents which give a magenta coloration with gallic acid in the presence of such weak alkalis as sodium bicarbonate, sodium sulphite ${ }^{3}$ and Rochelle salt suggests that, in the Mitchell reaction, there is first oxidation of ferrous sulphate to the ferric state and then oxidation of tannin by the ferric salt. It would appear that all the observations of ourselves and others can now

\begin{tabular}{|c|c|}
\hline $\begin{array}{c}\text { Trimethylgallic acid and hardwood } \\
\text { lignin }\end{array}$ & Gallic acid and tannins \\
\hline $\begin{array}{l}\text { (1) An excess of chlorine is required } \\
\text { in order to break down ether } \\
\text { links and form a phenol }{ }^{3} \text {. }\end{array}$ & Contain no ether links. \\
\hline $\begin{array}{l}\text { (2) The necessary oxidation is car- } \\
\text { ried out simultaneously by the } \\
\text { chlorine. }\end{array}$ & $\begin{array}{l}\text { A variety of oxidizing agents } \\
\text { may be used. }\end{array}$ \\
\hline $\begin{array}{l}\text { (3) The excess of chlorine must be } \\
\text { removed whilst the system is } \\
\text { acid since the coloured sub- } \\
\text { stance is specially sensitive to } \\
\text { oxidation in alkaline solutions. }\end{array}$ & $\begin{array}{l}\text { No excess of oxidizing agent } \\
\text { need be used. }\end{array}$ \\
\hline $\begin{array}{l}\text { (4) The system must be rendered } \\
\text { weakly alkaline before the char- } \\
\text { acteristic magenta colour de- } \\
\text { velops. }\end{array}$ & $\begin{array}{l}\text { The systemmust be weakly } \\
\text { alkaline tor the develop- } \\
\text { ment of the magenta colour. }\end{array}$ \\
\hline
\end{tabular}
be explained by assuming that these reactions take place in stages as shown in the accompanying table.
In the case of lignin, the importance of the third and fourth of the above steps is brought out as follows. Urea may be added to destroy excess of chlorine, and the coloration is given when the system is rendered alkaline. When sodium bicarbonate is added direct to freshly chlorinated wood, no colour is produced, even if urea is added afterwards. Sodium sulphite both removes excess chlorine and renders the system alkaline; but even in the presence of this reagent the colour is only transient, since it changes to brown on exposure to air. That atmospheric oxygen has little effect on the substance immediately responsible for the coloration when the medium is acid is shown by the observation that chlorinated beech. wood, from which excess chlorine had been removed by sulphurous acid, still gave the magenta coloration, when alkali was added, after an interval of six days.

Lastly, we have observed that the colour develops when gaseous chlorine is passed into a dilute aqueous solution of gallic acid containing an excess of basic lead acetate in suspension. The colour disappears in the presence of excess chlorine and does not reappear on adding sodium sulphite. On the other hand, if either beechwood or trimethylgallic acid is treated in the same way, no colour is developed; but if, after using an excess of chlorine, sodium sulphite is added, the colour appears as usual. In the first case, a small amount of chlorine causes sufficient oxidation for the production of the colour in the presence of the weakly alkaline basic lead acetate. Then, while the liquid is still alkaline, the coloured compound is destroyed by further chlorine. In the second case, phenol formation is not complete until sufficient chlorine has been passed to make the medium acid so that the colour is developed by sodium sulphite in the usual way.

\section{W. G. CAMpbeli.}

J. C. McGowan.

Section of Chemistry,

Forest Products Research Laboratory, Princes Risborough, Aylesbury, Bucks. May 10.

${ }^{1}$ Mitchell, C. A., Analyst, 48, 2 (1933).

${ }^{2}$ Campbell, W. G., Bryant, S. A., and Swann, G., Biochem. J., 31 1285 (1937)

${ }^{3}$ Campbell, W. G., McGowan, J. C., and Bryant, S. A., Biochem. J., 32, 2138 (1938).

'See Glasstone, S., Analyst, 50, 49 (1925) in this connexion.

\section{Ultra-Violet Chemi-Luminescence}

A RECENT report by $R$. Audubert ${ }^{1}$ on ultra-violet chemi-luminescence has provoked a good deal of discussion on the possible mechanism of the phenomenon. The phenomenon seems to be identical with the mitogenetic radiation ${ }^{2}$, a fact which was emphasized in the discussion following Audubert's paper (S. I. Wawilow, P. Pringsheim). In this connexion it may be of some interest to report briefly on our recent results, which have a bearing on some points raised in the discussion (Polanyi), and which suggest an interpretation of the radiation occurring in chemical reactions as a kind of sensitized fluorescence. A detailed report is in preparation.

The starting-point of our investigation was Frankenburger's hypothesis on the origin of mitogenetic radiation, from which we quote the following extract : "According to that interpretation [that of Haber and Willstätter] there may occur as 